\title{
The Effectiveness of Online Learning During the Covid-19 Pandemic in Asia A Literature Review
}

\author{
Veronica Eka Desi Natalia ${ }^{1}$, Anisa OS Pratama ${ }^{2}$, Zulaikha Fitriyanti ${ }^{3}$ \\ \{veronicanatalia82@gmail.com ${ }^{1}$, pratamanisa15@gmail.com² ${ }^{2}$, zulaikhafitriy@gmail.com ${ }^{3}$ \}
}

Master of Educational Administration, University of Lampung, Indonesia' ${ }^{1,3}$, Biologi Education, Raden Intan State Islamic University of Lampung, Indonesia ${ }^{2}$

\begin{abstract}
The emergence of the Covid-19 virus caused concern around the world in the fields of health, economy, social, politics and education. In the field of education, learning that was previously carried out in classrooms cannot be done temporarily. So that an alternative emerges in the learning method carried out, namely by implementing online and offline learning policies. This online learning is carried out in various countries in the world by utilizing online technology. The purpose of this study is to see the effectiveness of online learning that has been applied in various Asian countries. The method used in this study is a qualitative method with literature and empirical approaches. The data obtained comes from several government regulations, studies of national and international journals and phenomena that occur in the field. The results suggest that online learning conducted in Asian countries has the impact of accelerating the transition and reformation in learning are not yet perfect, so it requires cooperation of all elements of education to support the implementation of online learning.
\end{abstract}

Keywords: Online learning, Covid-19, education.

\section{Introduction}

The Corona Viruses Diseases (COVID-19) pandemic is a global pandemic that will hit many countries in the world in 2020 [1]. Covid-19 is an outbreak of a new type of disease that has never been previously identified in humans and the beginning of its occurrence in China, to be precise in Wuhan. Until now, COVID-19 has spread to various regions, including various cities in the world. The existence of COVID-19 has become a multidimensional problem that has disrupted various economic, social and educational situations. One of the impacts in the world of education is to cause a decrease in the quality of learning in students [2].

The regression in the quality of learning occurred due to the closure of schools to prevent the spread of the Covid-19 outbreak [1]. The pandemic emergency period requires the face-to-face learning system to be replaced with online learning so that the learning process continues [3]. Online learning is an educational innovation that utilizes information technology in learning [4]. The use of information technology supports distance learning, thus encouraging greater innovation in creating storage methods inside and outside the classroom [5]. Online learning uses a learning pattern that requires teachers to provide learning materials and teach students directly through remote tools (United Nations, 2020). Meanwhile, according to [6] online learning is a distance education system with the bile method where there are activities that are carried out separately from learning activities.

Online learning studies mean technology as a means and internet network as a system [4]. Based on this understanding, it can be seen that online learning is a learning 
system without face-to-face learning between teachers and students but done online and using the internet network. Teachers must ensure teaching and learning activities continue even though students are at home. Teachers are required to be able to design learning media as an innovation by utilizing online media. Teacher creativity is indispensable in online learning so that learning objectives can be achieved properly.

In Indonesia, the implementation of online learning is also used as an alternative solution in education today [7]. Online learning is carried out starting from various levels of education from early childhood, elementary, junior high school, high school and university. This research was conducted with the aim of providing an objective picture of how online learning activities were during the Covid-19 Pandemic, so that this becomes an evaluation material in creating bold learning that is effective in the midst of the Covid-19 Pandemic.

\section{Research Methods}

The process of searching for articles to be presented in this literature section is carried out using an internet search engine, which in this case is google scholar, by entering the keywords 'covid impact' and 'education'. From the searches carried out, there were found around 30-125 articles with a span of publication years from 2019-2020. The criteria for selecting the articles to be reviewed are as follows:

1. The research approach can be in the form of qualitative / quantitative / mix method.

2. The research was conducted in various Asian countries.

\section{Results and Discussions}

The results and discussion of the literature review article can be seen in table 1 .

Table 1. The Impact of Covid-19 in Education

\begin{tabular}{|c|c|c|c|c|c|c|}
\hline No & $\begin{array}{c}\text { Author } \\
\text { (Year) }\end{array}$ & Title & Country & Method & Platform & Findings \\
\hline 1 & $\begin{array}{l}\text { Bao (2020) } \\
{[8]}\end{array}$ & $\begin{array}{l}\text { COVID-19 } \\
\text { and online } \\
\text { teaching in } \\
\text { higher } \\
\text { education: A } \\
\text { case study of } \\
\text { Peking } \\
\text { University }\end{array}$ & China & Qualitative & $\begin{array}{l}\text { online video } \\
\text { tutoring and } \\
\text { email } \\
\text { guidance }\end{array}$ & $\begin{array}{l}\text { The study concludes with five } \\
\text { high impact principles for } \\
\text { getting online education: (a) } \\
\text { high relevance between } \\
\text { online learning design and } \\
\text { student learning, (b) effective } \\
\text { delivery of online teaching } \\
\text { information, (c) adequate } \\
\text { support provided by } \\
\text { teaching and teaching staff } \\
\text { to students; (d) high-quality } \\
\text { participation to increase the } \\
\text { breadth and depth of } \\
\text { student learning; and (e) } \\
\text { contingency plans for } \\
\text { dealing with unexpected } \\
\text { incidents of online education } \\
\text { platform. }\end{array}$ \\
\hline
\end{tabular}




\begin{tabular}{|c|c|c|c|c|c|}
\hline 2 & $\begin{array}{l}\text { Chung (2020) } \\
\text { [9] }\end{array}$ & $\begin{array}{l}\text { Online } \\
\text { Learning } \\
\text { Readiness } \\
\text { Among } \\
\text { University } \\
\text { Students in } \\
\text { Malaysia } \\
\text { Amidst } \\
\text { Covid-19 }\end{array}$ & Malaysia & Quantitative & $\begin{array}{l}\text { Google } \\
\text { Classroom } \\
\text { and YouTube } \\
\text { (vidio } \\
\text { learning) }\end{array}$ \\
\hline
\end{tabular}

Motivasi

Belajar

Mahasiswa

Fitriyani Pada

(2020) [4]

Daring

Selama

Pandemik

Covid- 19
The results of this study generally indicate little to moderate online learning readiness. Some of them are not ready for online learning due to lack of learner control, independent learning and effectiveness of online communication.

The results of this study indicate that the learning motivation of the sixth semester students of the primary school teacher education program in Kuningan is very good, where the percentage of the motivation score reaches $80.27 \%$. This research is expected to be an evaluation of various parties in organizing online learning in higher education, especially those involving motivation.

\begin{tabular}{|c|c|c|c|c|c|c|}
\hline 4 & $\begin{array}{l}\text { Priyadarshini } \\
\text { (2020) [10] }\end{array}$ & $\begin{array}{l}\text { E-readiness } \\
\text { of Senior } \\
\text { School } \\
\text { Learners to } \\
\text { Online } \\
\text { Learning } \\
\text { Transition } \\
\text { amid COVID- } \\
\text { 19 Lockdown } \\
\end{array}$ & India & Quantitative & $\begin{array}{l}\text { Online } \\
\text { learning }\end{array}$ & $\begin{array}{l}\text { The results showed that } \\
\text { online pedagogical } \\
\text { competencies and digital } \\
\text { skills of teachers and } \\
\text { students need to be } \\
\text { strengthened so that in the } \\
\text { future it will be better. }\end{array}$ \\
\hline 5 & $\begin{array}{l}\text { Toquero } \\
\text { (2020) [11] }\end{array}$ & $\begin{array}{l}\text { Challenges } \\
\text { and } \\
\text { Opportunities } \\
\text { for Higher } \\
\text { Education } \\
\text { amid the } \\
\text { COVID19 } \\
\text { Pandemic: } \\
\text { The } \\
\text { Philippine } \\
\text { Context }\end{array}$ & Filipina & Qualitative & $\begin{array}{l}\text { strengthen the } \\
\text { practices in } \\
\text { the curriculum }\end{array}$ & $\begin{array}{l}\text { The results confirm that } \\
\text { educational institutions } \\
\text { especially in the Philippines } \\
\text { are presented with } \\
\text { overcoming challenges in } \\
\text { their planning, } \\
\text { implementation, and } \\
\text { assessment systems. After } \\
\text { all, the global pandemic } \\
\text { opens up opportunities for } \\
\text { countries to improve their } \\
\text { modes of education and turn } \\
\text { their attention to emerging } \\
\text { technology. }\end{array}$ \\
\hline 6 & $\begin{array}{l}\text { Al-Mohair } \\
\text { (2020) [12] }\end{array}$ & $\begin{array}{l}\text { Study on } \\
\text { students' } \\
\text { experiences } \\
\text { about online } \\
\text { teaching }\end{array}$ & $\begin{array}{l}\text { Saudi } \\
\text { Arabia }\end{array}$ & Quantitative & $\begin{array}{l}\text { Instructor } \\
\text { Performance } \\
\text { Online } \\
\text { Teaching }\end{array}$ & $\begin{array}{l}\text { The results showed that } \\
\text { some students were quite } \\
\text { satisfied with the instructor's } \\
\text { performance, facilities and } \\
\text { internet network speed. }\end{array}$ \\
\hline
\end{tabular}




\begin{tabular}{|c|c|c|c|c|c|c|}
\hline & & $\begin{array}{l}\text { during } \\
\text { COVID-19 } \\
\text { Outbreak }\end{array}$ & & & & $\begin{array}{l}\text { Meanwhile, on the other } \\
\text { hand, some students were } \\
\text { dissatisfied because of } \\
\text { excessive assignments and } \\
\text { had to do assignments on } \\
\text { time. }\end{array}$ \\
\hline 7 & $\begin{array}{l}\text { Song (2020) } \\
{[13]}\end{array}$ & $\begin{array}{l}\text { Results of } \\
\text { Survey on } \\
\text { Online } \\
\text { Teaching for } \\
\text { Elementary } \\
\text { and } \\
\text { Secondary } \\
\text { Schools } \\
\text { During } \\
\text { COVID-19 } \\
\text { Prevention } \\
\text { and Control }\end{array}$ & China & Quantitative & $\begin{array}{l}\text { Online } \\
\text { interactive } \\
\text { Q\&A, Live } \\
\text { streaming, } \\
\text { Webcasting/V } \\
\text { idio on } \\
\text { demand, TV } \\
\text { learning, one- } \\
\text { to-one } \\
\text { tutoring }\end{array}$ & $\begin{array}{l}\text { secondary schools in China } \\
\text { are actively responding to } \\
\text { the call of the Ministry of } \\
\text { Education meeting to } \\
\text { "suspend classes without } \\
\text { delaying teaching and } \\
\text { learning" by adopting } \\
\text { online teaching in a well- } \\
\text { planned and well-organized } \\
\text { manner.. }\end{array}$ \\
\hline 8 & $\begin{array}{l}\text { Pratama } \\
(2020) \text { [7] }\end{array}$ & $\begin{array}{l}\text { Efektifitas } \\
\text { Penggunaan } \\
\text { Media } \\
\text { Edutainment } \\
\text { Di Tengah } \\
\text { Pandemi } \\
\text { Covid-19 }\end{array}$ & Indonesia & Mix method & $\begin{array}{l}\text { Media } \\
\text { Edutainment }\end{array}$ & $\begin{array}{l}\text { The results of the study } \\
\text { indicate that the majority of } \\
\text { students and teachers have } \\
\text { a positive perception of } \\
\text { using edutainment media (in } \\
\text { the questionnaire phase). In } \\
\text { addition, through the } \\
\text { edutainment media in online } \\
\text { learning, the achievement of } \\
\text { the cognitive aspects of } \\
\text { students (in the test phase) } \\
\text { also obtained positive } \\
\text { results. So that the overall } \\
\text { results show that the } \\
\text { edutainment media is } \\
\text { effective in accompanying } \\
\text { students to learn from home. }\end{array}$ \\
\hline 9 & $\begin{array}{l}\text { Chen (2020) } \\
{[14]}\end{array}$ & $\begin{array}{l}\text { Analysis of } \\
\text { User } \\
\text { Satisfaction } \\
\text { with Online } \\
\text { Education } \\
\text { Platforms in } \\
\text { China during } \\
\text { the COVID- } \\
\text { 19 Pandemic }\end{array}$ & China & Quantitative & $\begin{array}{l}\text { Ding Ding, } \\
\text { Tencent } \\
\text { Meeting, } \\
\text { Tencent Class, } \\
\text { Chaoxing } \\
\text { Learning, } \\
\text { Chinese } \\
\text { MOOC }\end{array}$ & $\begin{array}{l}\text { The conclusion suggests } \\
\text { that users' personal factors } \\
\text { do not have a direct influence } \\
\text { on user satisfaction, while } \\
\text { platform availability has the } \\
\text { greatest influence on user } \\
\text { satisfaction. }\end{array}$ \\
\hline 10 & $\begin{array}{l}\text { Ichsan (2020) } \\
\text { [1] }\end{array}$ & $\begin{array}{l}\text { Covid-19 Dan } \\
\text { E- Learning: } \\
\text { Perubahan } \\
\text { Strategi } \\
\text { Pembelajaran } \\
\text { Sains Dan } \\
\text { Lingkungan } \\
\text { Di SMP }\end{array}$ & Indonesia & Quantitative & $\begin{array}{l}\text { WhatsApp, } \\
\text { website, } \\
\text { Telegram, } \\
\text { Google } \\
\text { classroom, } \\
\text { Line, } \\
\text { Edmodo, } \\
\text { Microsoft } \\
\text { Zoom }\end{array}$ & $\begin{array}{l}\text { The results of this study } \\
\text { indicate that e-learning is } \\
\text { not yet perfect and needs to } \\
\text { be improved. }\end{array}$ \\
\hline
\end{tabular}


The results of this study found that there was a positive impact during the pandemic in the field of education in all countries in Asia. As in the Philippines, online learning activities have opened up opportunities to improve educational methods and shift to emerging technologies [11]. Likewise in Saudi Arabia, the implementation of online learning is planned to be carried out in the long term [12]. In line with that, all countries have made innovations in the world of education, such as Indonesia, China and Malaysia. The results showed that online learning activities in various countries in Asia received positive responses. This positive response is in line with the high level of research related to education during the pandemic. Based on Table 1, there are 10 articles that are analyzed consisting of seven quantitative studies, two qualitative studies and one mixed method research. This shows that education and research pay special attention to the corona pandemic. The world of education must innovate and make continuous changes so that the goals of education can be achieved.

In the implementation of online learning there are obstacles that are not only felt by many countries. The problems in online learning activities are in line with the main problem in almost all Asian countries, namely the lack of ability to understand material, this is due to the reach of the internet and the availability of facilities such as laptops / PCs/ Handphones which are inadequate and fully support the online learning process. For example, in India, due to the limited reach of the internet in areas, many students choose to live in cities in order to get a better internet signal [7]. In addition to facilities and the internet, the use of platforms as media in online learning also plays a role. This is very large [14]. In addition to platform use training, training also needs to be held to improve planning, implementation and assessment systems in online learning activities [11]. This is due to differences in face-to-face learning and online learning activities.

Indonesia uses several educational platforms to conduct online learning. In addition, there are several platforms used in Indonesia such as learning videos, interactive media, TV learning, Google Classroom, WhatsApp, Email Zoom, Moodle, Others [15]. China uses Video learning, online interactive, online streaming interactive Q\&A, Live streaming, Webcasting / Video on demand, TV learning. Meanwhile, Saudi Arabia, Malaysia, the Philippines and India used interactive learning videos. Online learning which is applied in several Asian countries uses online learning using learning videos. The platforms that are mostly used by Asian countries are interactive learning videos and online using (Google classroom). This platform can help in packaging learning and is interactive, thus helping students to achieve learning goals. This is in line with the use of online learning, most online teaching platforms can provide online learning and interactive modes, which can effectively meet existing teaching needs and provide feedback at any time [14]. This feed back ability has an influence on students' learning motivation, including independence in learning. Itriyani explained that motivation and learning independence during the Pandemic also affected learning goals so that they could be achieved. [4] Independence in learning is also important in exploring every aspect to be studied. Several studies have explained that there is a significant relationship between independent learning and learning outcomes both in direct learning and in distance learning [16]. Online learning that is applied shows that in using it is personal and does not have a direct effect, but the availability of the platform greatly affects user satisfaction. So that platforms in online learning during a pandemic must provide effective education-based information [14]. The success of education based on effective educational information is of course inseparable from government policies related to policy making in education during the pandemic. Both supporting educational facilities, learning media, and the applied curriculum. Example by providing cheap learning facilities, 
expanding the reach of the internet and providing free training to teachers in order to use the right educational platform. Meanwhile, the teacher's role is to be ready to learn new things and to be more creative in choosing learning methods for the implementation of the educational process. The role of students is also needed, namely to motivate themselves and start learning not because of obligation but the necessity of life so that they can further develop the potential they already have. The role of parents and society is very much needed in online learning, namely by supporting and accompanying students when participating in online learning. With the collaboration between the government, teachers, students, parents and the community, it is hoped that online learning activities can be carried out optimally so that the expected results can be achieved. In the implementation of online learning that is currently being implemented in various Asian countries there are several obstacles that are experienced. Research conducted in various countries provides an overview of the state of education during a pandemic. Online and offline learning policies are an option during this pandemic. As for the survey carried out in research in the field and seeing the facts that occur in education with the problems are shown in Figure 1.

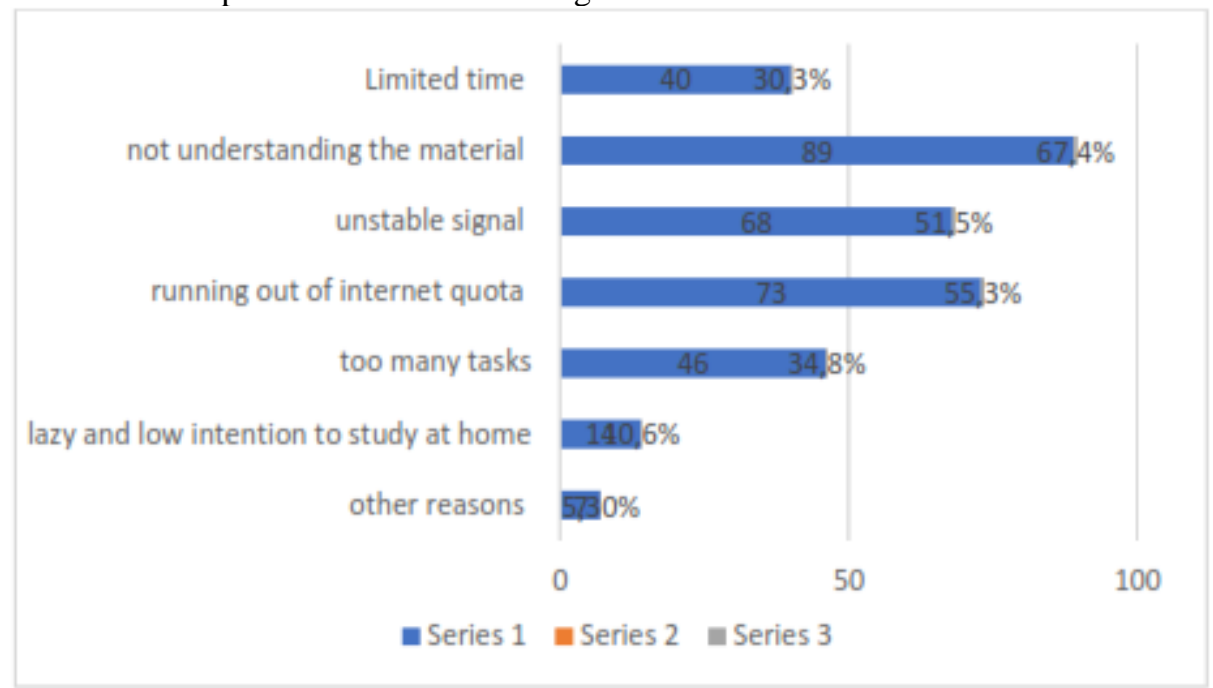

Figure 1. Obstacles during online learning

Based on figure 1 above, there are several obstacles experienced by students and according to a survey conducted on 337 students, the highest Based on Figure 1 above, there are several obstacles experienced by students and according to a survey conducted on 337 students, the highest obstacle was 89 students or $67.4 \%$ chose not to understand the material. Understanding of this material is closely related to the ability of teachers to package learning and the ability of students to receive teaching material. This is in line [7] which states that mastery by teachers and students of the media to be used is very necessary so that online learning activities can be carried out optimally. These obstacles in online learning need special attention, such as training of teachers / educators and students and good signal management.

Other obstacles besides not understanding the material are running out of internet quota as many as 73 students or $55.3 \%$, unstable signal as many as 68 students or $51.6 \%$, too many tasks as many as 46 students or $34.8 \%$, Limited time as many as 40 students or $30.3 \%$ lazy and low intention to study at home as many as 14 students or $10.6 \%$ and the rest chose other reasons 7 students or $5.3 \%$. Based on these constraints, it can be classified into 
several criteria, namely 1) obstacles that occur to students, namely laziness and low intention to study at home 2) constraints on learning media, namely material that is not conveyed 3) constraints on the internet network, namely unstable signals and running out of quota internet 4) constraints on assignment, namely limited time and too many tasks. Constraint 1 can be overcome with parental attention and motivation from students themselves. Constraint 2 can be overcome by selecting the right media so that the material can be conveyed. Obstacle 3 can be overcome by using a good internet network, of course the role of the government is expected to expand the internet network and provide additional quota assistance. Obstacle 4 can be overcome by providing training to teachers in order to choose the right assignment and according to the time provided so that students can do other activities such as gathering with family.

Apart from some of the obstacles above, online learning activities indirectly greatly support the transition from manual learning activities to online learning activities. Acceleration in the use of technology that must be experienced and studied by humans for the continuity of the learning process. Both teachers and students must be willing and able to learn to use technology so that learning objectives can be achieved and the learning process continues. So online learning activities force teachers and students to keep changing to adapt to technology so that learning media continues to experience better development.

\section{Conclusion}

Based on the literature analysis above, it can be seen that online learning allows teachers and students not to be at the same time and place. Covid-19 has caused almost all countries to use online learning as an alternative in preventing the outbreak. In Asia, online learning has had a positive impact as it accelerates migration and reforms in learning but it is still imperfect. The most effective online learning platforms used in Asia are interactive learning videos. The success of online learning requires the willingness and ability of all elements of education to support the implementation of online learning. Education will run well if the government, teachers, students, parents and society can carry out their respective roles well and this will lead to effective learning.

Acknowledgments. The authors thanks to LPDP (Lembaga Pengelolaan Dana Pendidikan ) for sponsorship.

\section{References}

[1] Ichsan, I. Z., Rahmayanti, H., Purwanto, A., Sigit, D. V., Kurniawan, E., Dewi, A. K., ... \& Marhento, G. 2020. Covid-19 Dan E-Learning: Perubahan Strategi Pembelajaran Sains Dan Lingkungan Di Smp. JINoP (Jurnal Inovasi Pembelajaran), 6(1). https://doi.org/10.22219/jinop.v6i1.1179

[2] Sahu, P. 2020. Penutupan Universitas Karena Penyakit Coronavirus 2019 (COVID-19): Dampak pada Pendidikan dan Kesehatan Mental Siswa dan Staf Akademik. Cureus, 2019 (April). https://doi.org/10.7759/cureus.7541

[3] Sintema, EJ 2020. Pengaruh COVID-19 terhadap Kinerja Siswa Kelas 12: Implikasi untuk Pendidikan STEM. Eurasia Jurnal Matematika, Sains dan Pendidikan Teknologi , 16 (7), 1-6. https://doi.org/10.29333/ejmste/7893

[4] Fitriyani, Y., Fauzi, I., \& Sari, M. Z. 2020. Motivasi Belajar Mahasiswa Pada Pembelajaran Daring Selama Pandemik Covid-19. Jurnal Kependidikan: Jurnal Hasil Penelitian dan Kajian 
Kepustakaan di Bidang Pendidikan, Pengajaran dan Pembelajaran, 6(2). https://doi.org/10.33394/jk.v6i2.2654

[5] Almeida, F., \& Simoes, J. 2019. Peran Permainan Serius, Gamifikasi, dan Industri 4.0.Alat dalam Paradigma Pendidikan 4.0. Teknologi Pendidikan Kontemporer, 10 (2),120-136. https://doi.org/10.30935/cet.554469.

[6] Mustofa, MI, Chodzirin, M., Sayekti, L., \& Fauzan, R. 2019. Formulasi Model Perkuliahan Daring sebagai Upaya Menekan Disparitas Kualitas Perguruan Tinggi.Walisongo Jurnal dari Informasi Teknologi, 1 (2), 151. https://doi.org/10.21580/wjit.2019.1.2.4067.

[7] Pratama, L. D., Lestari, W., \& Astutik, I. 2020. Efektifitas Penggunaan Media Edutainment Di Tengah Pandemi Covid-19. AKSIOMA: Jurnal Program Studi Pendidikan Matematika, 9(2). https://doi.org/10.24127/ajpm.v9i2.2783.

[8] Bao, W. 2020. COVID-19 and online teaching in higher education: A case study of Peking University. Human Behavior and Emerging Technologies, 2(2), 113-115. https://doi.org/10.1002/h

[9] Chung, E., Subramaniam, G., \& Dass, L. C. 2020. Online Learning Readiness Among University Students in Malaysia Amidst Covid-19. Asian Journal of University Education, 16(2), 45-58. https://doi.org/10.24191/ajue.v16i2.1029

[10] Priyadarshini, A., \& Bhaumik, R. 2020. E-readiness of Senior School Learners to Online Learning Transition amid COVID-19 Lockdown. Asian Journal of Distance Education, 15(1), 244-256

[11] Toquero, C. M. 2020. Challenges and opportunities for higher education amid the COVID-19 pandemic: The Philippine context. Pedagogical Research, 5(4) https://doi.org/10.29333/pr/7947

[12] Al-Mohair, H., \& Alwahaishi, S. 2020. Study on students' experiences about online teaching during COVID-19 Outbreak. Technium Social Sciences Journal, 8, 102-116.

[13] Song, H., Wu, J., \& Zhi, T. 2020. Results of Survey on Online Teaching for Elementary and Secondary Schools During COVID-19 Prevention and Control. ECNU Review of Education, 2096531120930021. https://doi.org/10.1177\%2F2096531120930021

[14] Chen, T., Peng, L., Yin, X., Rong, J., Yang, J., \& Cong, G. 2020. Analysis of User Satisfaction with Online Education Platforms in China during the COVID-19 Pandemic. In Healthcare (Vol. 8, No. 3, p. 200). Multidisciplinary Digital Publishing Institute. https://doi.org/10.3390/healthcare8030200

[15] Gunawan, G., Suranti, N. M. Y., \& Fathoroni, F. 2020. Variations of Models and Learning Platforms for Prospective Teachers During the COVID-19 Pandemic Period. Indonesian Journal of $\begin{array}{llll}\text { Teacher } & \text { Education, } & \text { 61-70. } & \text { Retrieved }\end{array}$ fromhttps://journal.publicationcenter.com/index.php/ijte/article/view/95

[16] Tahar, I., \& Enceng. 2006. Hubungan Kemandirian Belajar dan Hasil Belajar pada Pendidikan Jarak Jauh. Jurnal Pendidikan Terbuka Dan Jarak Jauh, 7(2), 91-101.

[17] Nurhayati, E. 2019. Penerapan Buku Saku dengan Pendekatan Saintifik untuk Meningkatkan Motivasi dan Hasil Belajar Siswa Pasca Gempa Bumi. Jurnal Kependidikan: Jurnal Hasil Penelitian Dan Kajian Kepustakaan Di Bidang Pendidikan, Pengajaran Dan Pembelajaran, 5(2), 94-99. https://doi.org/10.33394/jk.v5i2.1804 